\title{
DYNAMIC OPTIMISATION OF DEEP-LEVEL MINE REFRIGERATION CONTROL
}

\author{
P.F.H. Peach ${ }^{1 \# *}$, J.I.G. Bredenkamp ${ }^{1 \dagger} \&$ J.F. van Rensburg ${ }^{1}$
}

\section{ARTICLE INFO}

Article details

Presented at the $29^{\text {th }}$ annual conference of the Southern African Institute for Industrial Engineering (SAIIE), held from 24-26 October 2018 in Stellenbosch, South Africa

Available online 9 Nov 2018

Contact details

Corresponding author pfhpeach@researchtoolbox.com

Author affiliations

1 Centre for Research and Continued Engineering Development (CRCED), North-West University, Pretoria, South Africa

\# Author is enrolled for a PhD degree in Mechanical Engineering at the North-West University's Centre for Research and Continued Engineering Development (CRCED) in Pretoria, South Africa

$\dagger \quad$ Author is a post-doctoral student at the North-West University's Centre for Research and Continued Engineering Development (CRCED) in Pretoria, South Africa

DOI

http://dx.doi.org/10.7166/29-3-2065
ABSTRACT

Artificial cooling remains vital to the deep-level mining industry. This is mainly to ensure a safe underground working environment. Unfortunately, the refrigeration systems of South African gold mines are outdated. Aging infrastructure and increasing distances to active mining areas present this industry with a unique set of cooling challenges. Mines are deeper and more complex than ever, yet their refrigeration systems operate according to original design specifications. The importance of mine refrigeration systems adapting to a dynamic environment becomes evident. One solution to this challenge is to re-evaluate the control of refrigeration systems based on dynamic cooling needs. Control optimisation strategies were implemented on a case study to improve the overall performance of a refrigeration system. The implementation of these strategies resulted in multiple benefits for the mine. The operational performance of the refrigeration system was optimised, resulting in both service delivery improvements and energy efficiency. During summer months the chill dam temperature decreased by $1^{\circ} \mathrm{C}$ at a lower energy consumption of $38 \mathrm{MWh}$ per day. This accumulates to a financial cost saving of R9 million per annum. This study proves that operational performance increases are possible through dynamic control optimisation of deep-level mine refrigeration systems.

\section{OPSOMMING}

Kunsmatige verkoeling bly onontbeerlik vir die ondergrondse mynboubedryf. Dit is hoofsaaklik om 'n veilige werksomgewing te verseker. Ongelukkig is die verkoelingstelsels van Suid-Afrikaanse goudmyne verouderd. Verouderde infrastruktuur en die toenemende afstande na aktiewe werksareas lei tot unieke verkoelings uitdagings. Myne is dieper en meer kompleks as ooit tevore, maar die verkoelingstelsels funksioneer steeds volgens oorspronklike ontwerpspesifikasies. Dit is duidelik dat huidige verkoelingstelsels nie opgewasse is vir die veranderende omstandighede nie. Een oplossing vir hierdie unieke uitdaging is om die beheer van verkoelingstelsels te herevalueer om aan veranderende verkoelings behoeftes te voorsien. Optimering strategieë is geïmplementeer op ' $n$ gevallestudie om die algehele dienslewering van ' $n$ verkoelingstelsel te verbeter. Implementering van hierdie strategieë het verskeie voordele tot gevolg gehad, onder andere verbeterings in dienslewering teen 'n laer energie verbruik. Gedurende die somermaande het die temperatuur van die koue water dam gedaal met $1^{\circ} \mathrm{C}$ teen ' $\mathrm{n}$ verminderde energieverbruik van $38 \mathrm{MWh}$ per dag. Dit lei tot ' $\mathrm{n}$ finansiële kostebesparing van R9 miljoen per jaar. Hierdie studie bewys dus dat operasionele verbeterings in dienslewering moontlik is deur dinamiese beheer van myn verkoelingstelsels. 
The South African gold mining sector is an industry synonymous with the term 'deep-level mining'. This phenomenon is easy to understand, as eight of the world's ten deepest underground mines are gold mines situated in South Africa [1]. These mines can reach distances of up to $4 \mathrm{~km}$ below the surface, where virgin rock temperatures exceeding $60^{\circ} \mathrm{C}$ have been measured at stope faces [2], [3], [4]. Workers are exposed to these harsh environments, as mechanisation of this industry is impeded by the fact that the majority of gold ore deposits are narrow reefs [2]. These factors highlight the importance of effective artificial cooling and ventilation for a safe working environment.

This industry, however, faces numerous challenges that affect the effective operation of their refrigeration systems. Ore bodies are being depleted as they are mined out over time, forcing the mine to expand its active mining areas [5], [6]. Mines are becoming deeper and more complex as ore bodies are located deeper underground and further from the shaft area [5], [7]. However, it is still expected that existing refrigeration infrastructure with outdated control strategies will provide sufficient cooling to 'larger', more complex mines. This leads to major operational inefficiencies [8].

The problem with the existing refrigeration infrastructure is that it is outdated. A study found that the average age of most of the refrigeration systems on gold mines located in the Free State province is more than 25 years [8]. Some of these systems have been in operation for more than 35 years [8]. Two to three decades can completely transform a mine and its cooling needs, while the refrigeration equipment's effectiveness deteriorates substantially over time without proper maintenance [3], [9]. The solution, however, is not as easy as installing new refrigeration infrastructure where current cooling is ineffective or insufficient. This is purely because of the economic and financial stresses on this industry [3].

Projections estimate that gold production in South Africa will fall below 50 tonnes per annum by 2023 [10]. According to the Hubbert Peak Theory, the end of exploitable gold reserves in South Africa will be reached somewhere during 2030 if current mining trends continue [10]. Therefore, the life-of-mine in most cases does not justify the capital expenditure on new infrastructure and installations. This means that the current infrastructure needs to be exploited to keep operating costs down during this period of extreme uncertainty for the industry.

Attempting to run 25-year-old machinery based on its original design specifications in a dynamic environment such as a gold mine leads to ineffective operational performance. Combining all the above-mentioned challenges, requirements and constraints, there is a clear need to implement updated and dynamic deep-level mine refrigeration control for improved operational performance - that is, for improved service delivery at minimised operational costs.

\section{DEEP-LEVEL MINE REFRIGERATION}

\subsection{Preamble}

The concept of refrigeration in the deep-level mining environment will be discussed in this section. The importance of refrigeration systems for the mining environment will be highlighted. Different refrigeration system control methods, and how they impact the operation of the system, are briefly discussed. The section is concluded with a brief literature survey of research conducted on refrigeration system control.

\subsection{Refrigeration concept in deep-level mines [11]}

Most refrigeration machines installed in deep-level mines make use of the vapour-compression cycle to extract heat from warm water. The basic vapour-compression cycle is divided into four stages, starting with the compression of a refrigerant to a super-heated gaseous state. Heat rejection then takes place in the condenser to cool the super-heated vapour into a liquid. This liquid is flashed over an expansion valve, resulting in a temperature decrease. The vapour, now at low temperature, absorbs heat in the evaporator before the cycle is repeated. Tube-in-shell heat exchangers are widely used in the mining industry's chillers, with water flowing through the tubes while refrigerant passes over them within a pressurised vessel [12]. 
The water passing through the condenser vessel is returned to cooling towers for heat rejection through latent and sensible heat transfer with ambient air. Cooling towers are filled with a corrugated material to increase the contact area between the air and the water. Large mechanical fans are used to force air through the fill, further aiding in heat exchange. This is a semi-closed loop system, with the water continually passing through the chiller condenser vessel and cooling towers when the chiller is running.

The cold water required for ventilation and mining purposes is chilled in the evaporator side of the chiller. The refrigerant absorbs the heat from the passing water, resulting in a temperature decrease. For ventilation purposes, the chilled water is then fed to a bulk air cooler (BAC), which exchanges heat between the chilled water and the ambient air. The chilled water required for mining is transferred to holding dams where it is distributed throughout the mine according to demand. A simplified illustration of the refrigeration concept in deep-level mines can be seen in Figure 1.

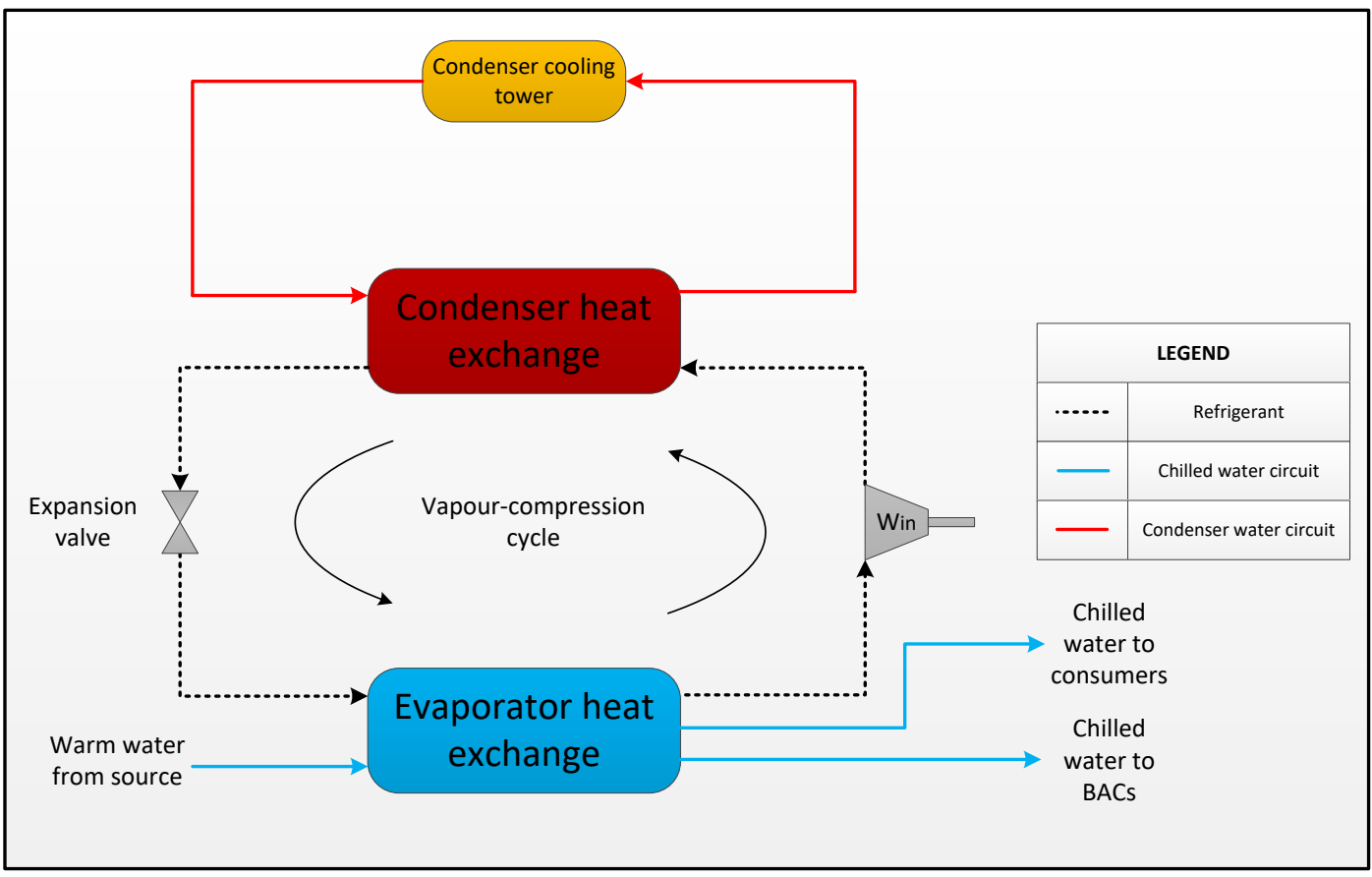

Figure 1: Refrigeration concept in deep-level mines [11]

\subsection{Role of refrigeration in deep-level mining}

South African deep-level gold mines typically require large amounts of service water for their operations. In the past, this service water was usually required for mining purposes such as dust suppression and machine operation. As mines in South Africa became deeper, the chilled water supplied by refrigeration systems became more vital for ventilation purposes. As the depth of the mines increased, the cooling capacity of the air became inadequate due to factors such as auto-compression and the low specific heat of air [4], [11], [13].

\subsubsection{Service water use}

Chilled service water sent underground is primarily used for the following purposes [4], [11], [13]:

- Dust suppression

- $\quad$ Equipment operation (e.g., drills, cylinders)

- Working face cooling

- Ore transport (water jet cleaning)

- $\quad$ Energy recovery (such as Pelton wheels or three-chamber pipe feeder systems)

\subsubsection{Ventilation}

The Mine Health and Safety Act No. 967 of 1996 sets out the maximum limits for underground temperatures in working areas. This Act sets the maximum allowable wet-bulb temperature in 
working and stoping areas at $27.5^{\circ} \mathrm{C}$ and $32.5^{\circ} \mathrm{C}$ respectively [14]. This makes the following chilled water consumers crucial for the purposes of ventilation [11], [15]:

- $\quad$ Surface BACs

- Underground BACs

- Mobile cooling units

- $\quad$ Air atomisers/movers

\subsection{Refrigeration system control}

There are multiple methods to control the output temperature of the evaporator water on modern chillers. Three of the most common methods used on large industrial refrigeration systems are [11]:

- Compressor guide vane control

- Evaporator water flow control

- Condenser water flow control

\subsubsection{Compressor guide vane control}

Variable guide vanes are located at the inlet of the chiller compressor, and are used to change the angle at which the refrigerant impacts the impeller. The use of guide vanes results in a decreased energy requirement when the compressor is not required to run at full load. For chillers, maximum heat exchange happens at full load; and so there is less heat exchange as the guide vane angle approaches a minimum. The minimum guide vane angle is limited to prevent the compressor from surging (flow of fluid changing direction within the compressor) [16].

\subsubsection{Evaporator water flow control}

If it is assumed that a fixed amount of heat exchange (q) is present in the evaporator vessel, then altering the amount of water (flow rate) through the evaporator circuit will result in a change in outlet temperature. This is mathematically illustrated by Equation 1 below. Less water passing through the vessel will result in a lower outlet temperature, as constant cooling is provided to a smaller volume of water. Increasing the flow rate through the vessel will have the opposite effect, resulting in higher outlet temperatures.

$q=\dot{m} C_{p} \Delta T$

(Equation 1)

$\dot{m}=\frac{C_{p}\left(T_{\text {in }}-T_{\text {out }}\right)}{q}$

where:

$\begin{array}{ll}q & \text { - cooling provided }[\mathrm{kW}] \\ \dot{m} & \text { - mass flow rate of water }[\mathrm{kg} / \mathrm{s}] \\ C_{p} & \text { - Specific heat of water }-4.187[\mathrm{~kJ} / \mathrm{kg} \cdot \mathrm{K}] \\ T_{\text {in }} & \text { - Inlet water temperature }\left[{ }^{\circ} \mathrm{C}\right] \\ T_{\text {out }} & \text { - Outlet water temperature }\left[{ }^{\circ} \mathrm{C}\right]\end{array}$

According to Equation 1, if the parameters $q$ and $T_{\text {in }}$ remain constant, the outlet temperature will change with a change in $\dot{m}$. The cooling provided in the evaporator, as stipulated by Equation 1 , is also used to determine the chiller's coefficient of performance (COP), which is a measure of how much cooling is provided for each electrical unit consumed by the chiller compressor motor [12].

\subsubsection{Condenser water flow control}

The principle behind condenser flow control is the same as that for evaporator flow control, functioning on the same principle illustrated by Equation 1, with the only difference that it is implemented on the condenser circuit of the chiller. The main goal with condenser water flow control, however, is to alter the amount of heat rejected within the condenser vessel. Increasing heat rejection within the condenser will result in lower refrigerant temperatures, in turn decreasing evaporator water outlet temperatures. This is because a higher heat absorption capacity is available in the evaporator due to lower refrigerant temperatures. 


\subsubsection{Integrated control method}

These three control methods are usually combined in the large refrigeration systems found on gold mines. Guide vane and condenser flow control determine the amount of heat rejection and absorption capacity available within the refrigerant circuit. Evaporator water flow control determines the amount of service water to be cooled and thus the exit temperature of that water. It should be noted that the explanations given in this section are only to illustrate the principles of different control methods. In reality, none of the parameters associated with chiller control remains constant, meaning that all affect each other as the entire system is integrated. [11]

\subsection{Research relevant to refrigeration system control}

Multiple studies have been conducted over the past few years on the optimisation of refrigeration control on deep-level mines. Most of these studies, however, focused on cost-savings initiatives through load management and energy efficiency initiatives as part of Eskom's demand side management (DSM) programme. Previous studies conducted on refrigeration systems were evaluated on the criteria presented in Table 1. It becomes evident that service delivery improvements were not the focus, as only two out of the 12 studies were conducted with the aim of improving service delivery. An overview of these two studies is presented after Table 1.

Table 1: Evaluation summary of previous studies

\begin{tabular}{|c|c|c|c|c|c|c|}
\hline Study & 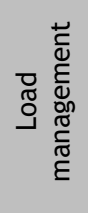 & 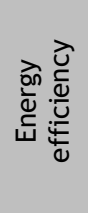 & ฝૂ & on & 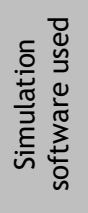 & 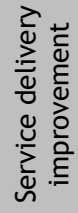 \\
\hline Engles [17] & $\checkmark$ & $\checkmark$ & $\checkmark$ & & $\checkmark$ & \\
\hline Jv Rensburg [3] & $\checkmark$ & $\checkmark$ & & $\checkmark$ & $\checkmark$ & $\checkmark$ \\
\hline Maré [9] & & $\checkmark$ & $\checkmark$ & $\checkmark$ & $\checkmark$ & \\
\hline Moropa [15] & $\checkmark$ & & $\checkmark$ & & & \\
\hline Nel [18] & & $\checkmark$ & $\checkmark$ & $\checkmark$ & & \\
\hline Oberholzer [8] & & $\checkmark$ & $\checkmark$ & & $\checkmark$ & $\checkmark$ \\
\hline Peach [19] & $\checkmark$ & & $\checkmark$ & $\checkmark$ & $\checkmark$ & \\
\hline Schoeman [13] & & $\checkmark$ & $\checkmark$ & & $\checkmark$ & \\
\hline Schutte [20], [21] & $\checkmark$ & $\checkmark$ & $\checkmark$ & & $\checkmark$ & \\
\hline van der Bijl [22] & $\checkmark$ & & $\checkmark$ & & $\checkmark$ & \\
\hline Vermeulen [23] & $\checkmark$ & & $\checkmark$ & & $\checkmark$ & \\
\hline
\end{tabular}

Jansen van Rensburg [3] showed that improved service delivery in refrigeration systems is possible through a combination of maintenance, reconfiguration, and optimised control strategies.

Oberholzer's [8] research was aimed at reconfiguring mine cooling auxiliaries for optimal operation. The study proved successful, and operational benefits (energy savings) were clearly realised after reconfiguration strategies were implemented in conjunction with control optimisation. Reconfiguration of mine cooling auxiliaries is unfortunately an expensive endeavour, requiring upgrades and alterations to existing infrastructure.

When viewing the outcomes of previous research, it becomes clear that the goal for most of these researchers was to improve cost savings on deep-level mine refrigeration systems without negatively influencing the operation. However, two studies were identified that did focus on service delivery improvements but that required capital expenditure for maintenance, reconfiguration, and installations. This can be an expensive endeavour, depending on the extent of the reconfiguration required. Improving performance on refrigeration systems without time-consuming or costly 
infrastructure alterations is important, considering the economic position in which South African deep-level gold mines currently find themselves [24].

\section{DYNAMIC OPTIMISATION OF DEEP-LEVEL MINE REFRIGERATION CONTROL}

A case study was identified on a South African deep-level gold mine. Due to confidentially agreements, the case study will hereafter be referred to as Mine A. The methodology for the dynamic optimisation of deep-level mine refrigeration control is schematically illustrated in Figure 2 . These steps are discussed in more detail below.

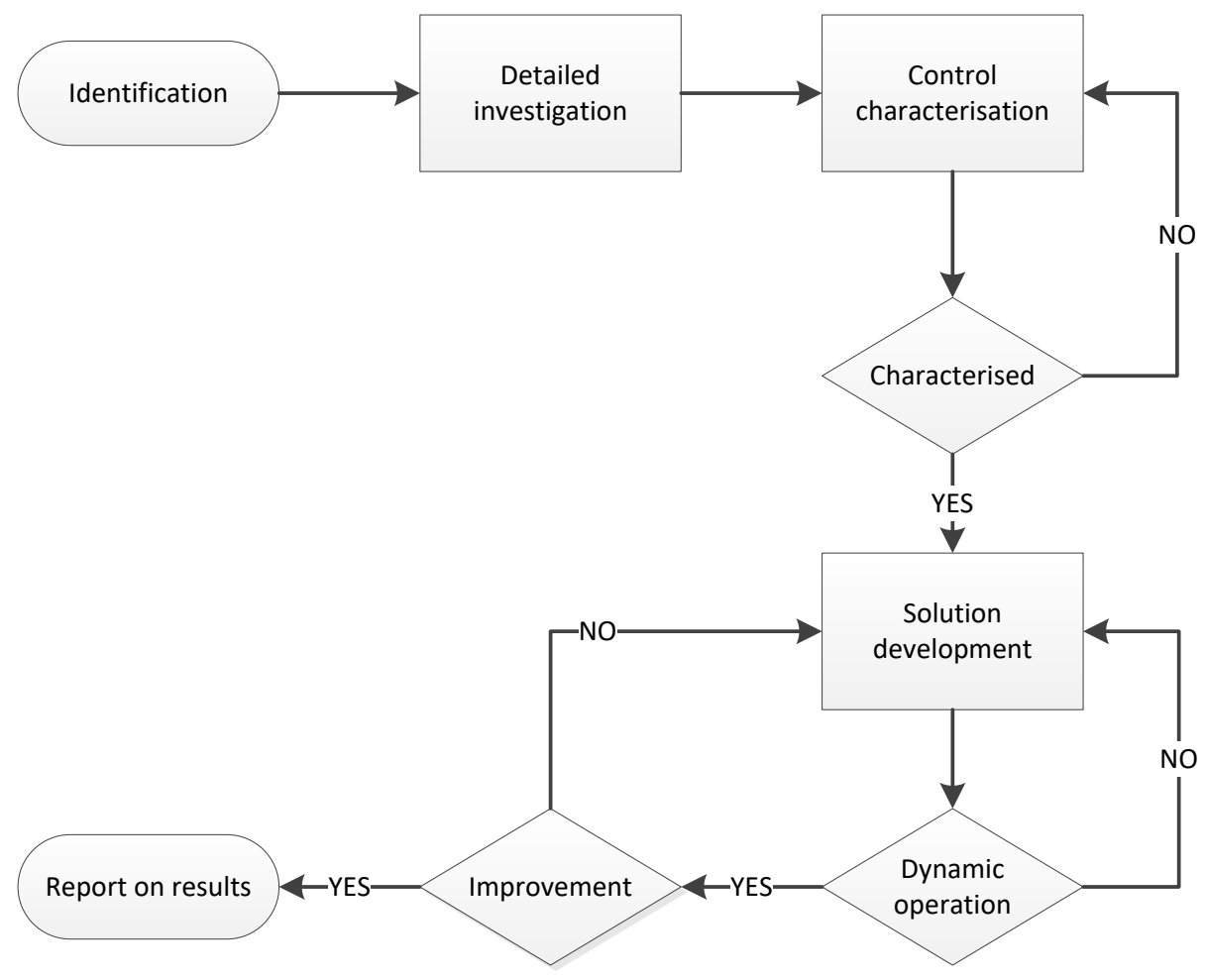

Figure 2: Methodology flow chart

\subsection{Identification}

The refrigeration system on Mine A was commissioned in 1991/1992. At the time of this study, the refrigeration system had been in operation for more than 25 years. The mine itself has witnessed drastic changes in those 25 years, with the addition of a sub-66L decline that expanded the active mining areas far beyond the original design of the mine. The service water requirements of the mine also drastically increased, with a sub-66L decline chilled service water demand of $80-120 \mathrm{l} / \mathrm{s}$. This inevitably forced the mine to start up an additional refrigeration machine to accommodate the additional water demand. However, the operating parameters of the refrigeration system remained fixed at the original design that was specified during commissioning.

The initial investigation thus identified the case study with all the pre-requisites for dynamic optimisation of refrigeration control on this system. The next step entails a detailed investigation and characterisation of the system.

\subsection{Detailed investigation and control characterisation}

The basis of a detailed investigation and characterisation is to understand the system and how it will react to control changes. The first step is to become familiar with the layout and the installed equipment. This includes understanding how each component is connected and how they affect one another. Compiling a detailed layout based on information obtained from site visits is the best way to familiarise oneself with the system under investigation. Figure 3 shows a simplified layout of the refrigeration system located at Mine A. 


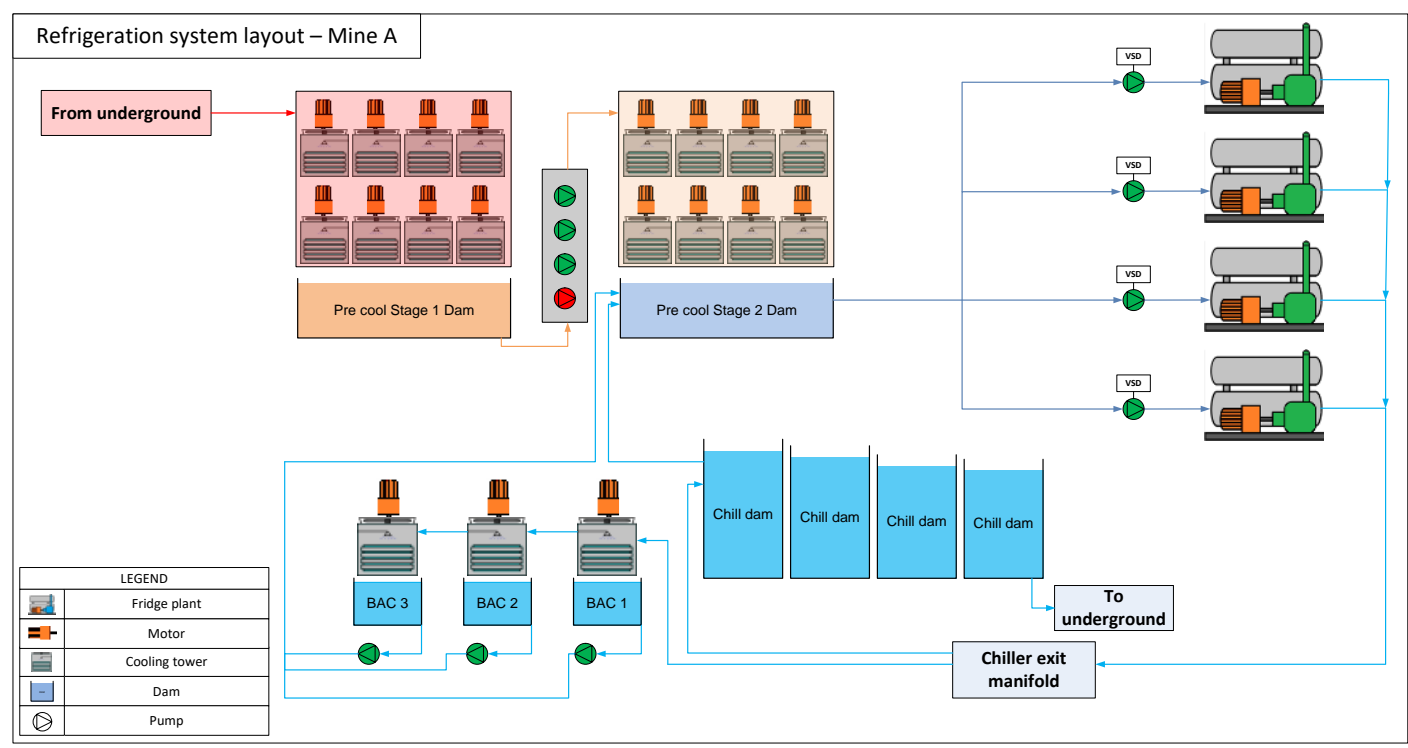

Figure 3: Simplified refrigeration system layout - Mine A

Hot service water from underground enters the system and is transferred through dual-stage precooling. From re-cooling dam 2 (PCD2) the water is transferred through the chillers and cooled down. The evaporator and condenser pumps are fitted with variable speed drives (VSDs), allowing the flow to be altered between safe limits (in this case, between $210 \mathrm{l} / \mathrm{s}$ and $309 \mathrm{l} / \mathrm{s}$ ). The chilled water then heads to a manifold and splits between the BACs and the surface chill dam (SCD). The return water from the BACs and overflow water from the SCD is recycled to PCD2. This process happens continuously to supply the mine with chilled service water and cool ventilation air.

Once the components' specifications and how they react to one-another are known, the control of the system needs to be investigated. In the case of Mine A, three separate control systems were present: chiller compressor guide vane control, evaporator flow control, and condenser flow control. The guide vane control is implemented automatically through a programmable logic controller (PLC). A real-time energy management system (EnMS) is responsible for determining the evaporator and condenser flow, based on an evaporator outlet temperature set-point. The EnMS determines the required flow rate by assuming that the current cooling provided in the evaporator or condenser vessel is constant. It then alters the flow to achieve the desired set-point. This is presented mathematically by Equation 2 and Equation 3.

$q_{C U R}=\dot{m}_{C U R} C_{p}\left(T_{\text {in }}-T_{\text {out }}\right)$

(Equation 2)

$\dot{m}_{N E W}=\frac{q_{C U R}}{C_{p}\left(T_{i n}-T_{S P}\right)}$

(Equation 3)

where:

$q_{\text {CUR }} \quad$ - Current cooling provided [kW]

$\dot{m}_{C U R}$ - Current flow rate [l/s]

$\dot{m}_{N E W}$ - Required flow rate to reach temperature set-point [l/s]

$C_{p} \quad$ - Specific heat of water at $4.187[\mathrm{~kJ} / \mathrm{kg} \cdot \mathrm{K}]$

$T_{\text {in }} \quad$ - Inlet water temperature $\left[{ }^{\circ} \mathrm{C}\right]$

$T_{\text {out }} \quad$ - Outlet water temperature $\left[{ }^{\circ} \mathrm{C}\right]$

$T_{S P} \quad$ - Desired set-point temperature $\left[{ }^{\circ} \mathrm{C}\right]$

As the control is implemented in real-time, the flow continually adapts between safety limits to ensure a constant evaporator outlet temperature. The pre-implementation set-point for Mine A was $3^{\circ} \mathrm{C}$, resulting in all the chillers delivering a minimum flow of $210 \mathrm{l} / \mathrm{s}$ to achieve the required setpoint. This constant flow meant that the system could not adjust in response to external changes. Due to the age of the system and the requirements of the mine, the actual outlet temperature achieved was $6^{\circ} \mathrm{C}$, double that of the required set-point. When these intricacies of the system and 
its control are fully understood, development of a dynamic control solution for improved operation can commence.

\subsection{Control solution development and implementation}

Optimisation is possible through increasing the evaporator set-point stipulated in Equation 3. This will allow for automatic adjustment of the evaporator flow to account dynamically for changes in inputs such as ambient temperature, water inlet temperature, and water demand. Increasing the set-point might sound counter-productive when the goal is to increase performance, which at first glance is expected to be achieved through a lower set-point. What the set-point increase does, however, is to increase the amount of cooling provided by an individual chiller by altering the flow, while only slightly affecting the outlet temperature.

As the ambient conditions during summer and winter vary greatly in South Africa, different setpoints for these two seasons will be considered. The proposed evaporator outlet set-point for summer and winter months can be seen in Table 2 . The compressor guide vane angle and condenser flow control will be left unaltered.

Table 2: Current and proposed evaporator water outlet temperature

\begin{tabular}{lcc}
\hline Season & Current set-point & Proposed set-point \\
\hline Summer & $3^{\circ} \mathrm{C}$ & $4^{\circ} \mathrm{C}$ \\
Winter & $3^{\circ} \mathrm{C}$ & $5^{\circ} \mathrm{C}$
\end{tabular}

The set-points proposed in Table 2 were determined on the basis of practical experience of the specific refrigeration system, along with quick simulations. The simulations confirmed the theoretical impact of the updated set-points before implementation. After discussions with Mine A's ventilation and management personnel, the set-points were approved and implemented.

\section{RESULTS AND DISCUSSION}

\subsection{Introduction}

One week of operation for summer and winter respectively was compared with a baseline for each period, and used to determine the effect of the optimised control strategy on the refrigeration system. The results are presented in 24-hourly averaged graphs for each comparison period. Before the improvement in the new control philosophy can be determined, it is important to ensure that accurate comparisons are presented. The ambient conditions of the baseline and optimised periods therefore need to be similar. This is due to the effect that ambient conditions may have on the operational outputs of surface refrigeration systems.

Figure 4 illustrates the ambient temperature comparison between the baseline and the optimised periods for both summer and winter.

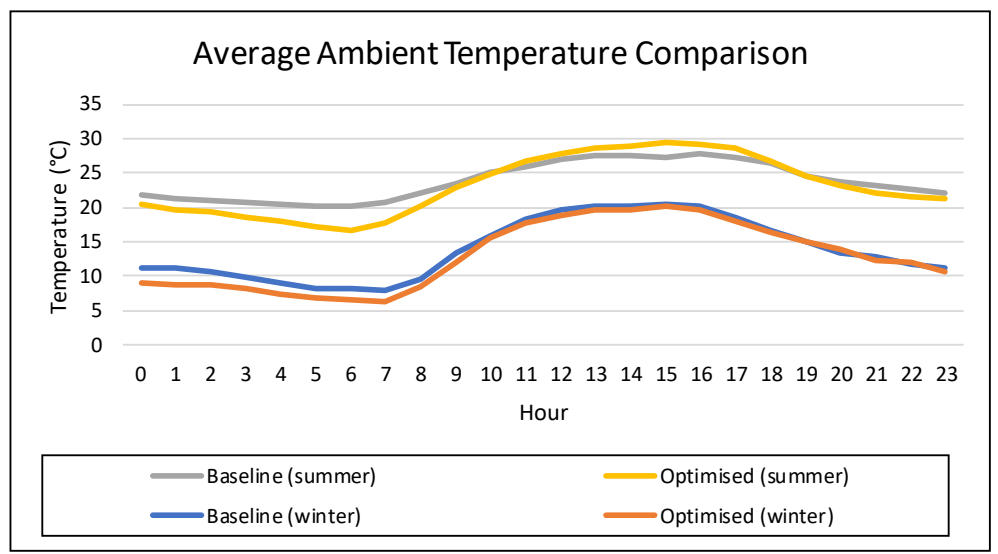

Figure 4: Ambient temperature comparison (see online version for colour) 


\subsection{Summer}

The optimised control philosophy resulted in 15 per cent less cooling supplied by the refrigeration system on Mine A. Even with this reduced cooling provided by the system, the amount of cooling sent underground increased over the same period. Due to the system's configuration, however, the electrical demand of the chillers and auxiliaries reduced by 18 per cent. After implementation, the average COP of the chillers thus increased from 4.9 to 5.2. This represented an overall operational performance increase of five per cent. Figure 5 presents a flow chart of the effects experienced throughout the rest of the refrigeration system, and how they interacted.

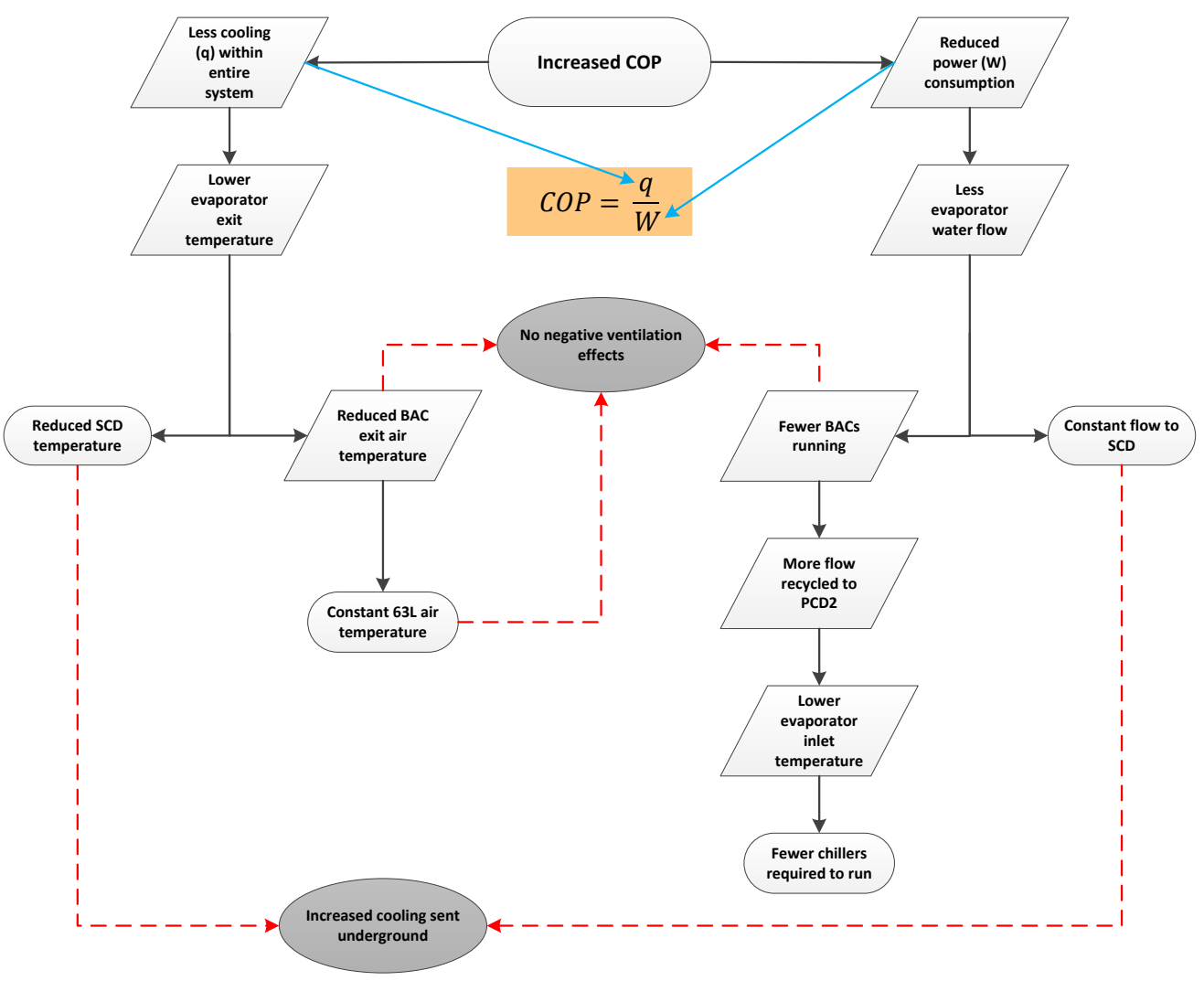

Figure 5: Summer results flow chart

The reduced cooling provided by the system did not negatively affect the mine, as the evaporator outlet temperature decreased, as seen in Figure 6.

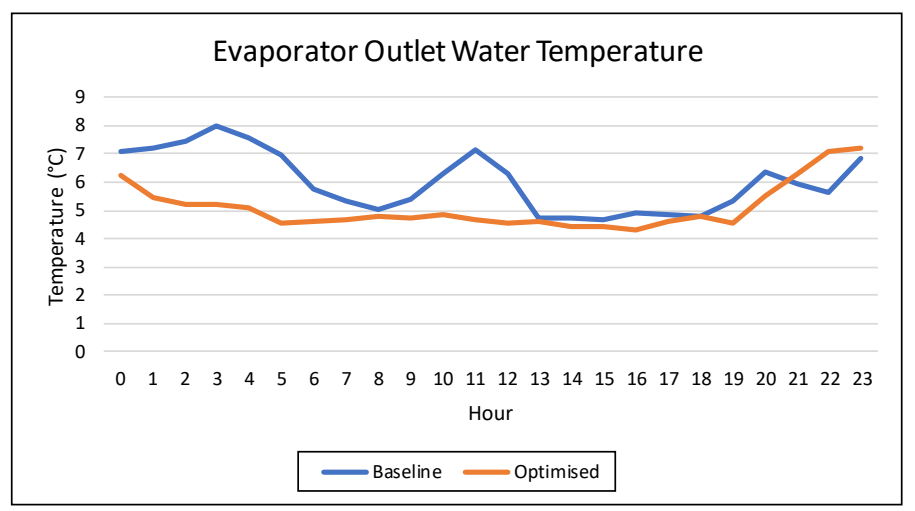

Figure 6: Average evaporator outlet water temperature comparison - summer (see online version for colour) 
This resulted in a decrease in SCD and BAC outlet air temperatures, as illustrated by Figure 7 and Figure 8 respectively. The underground air temperature as measured on $63 \mathrm{~L}$ remained constant at $28^{\circ} \mathrm{C}$ dry-bulb for both periods, proving that underground cooling was not affected by the optimised control strategy.

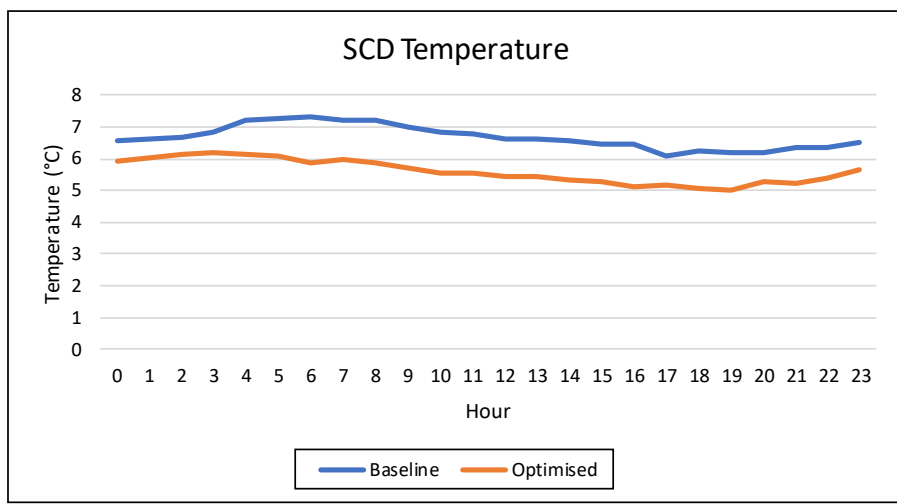

Figure 7: Average SCD temperature comparison - summer (see online version for colour)

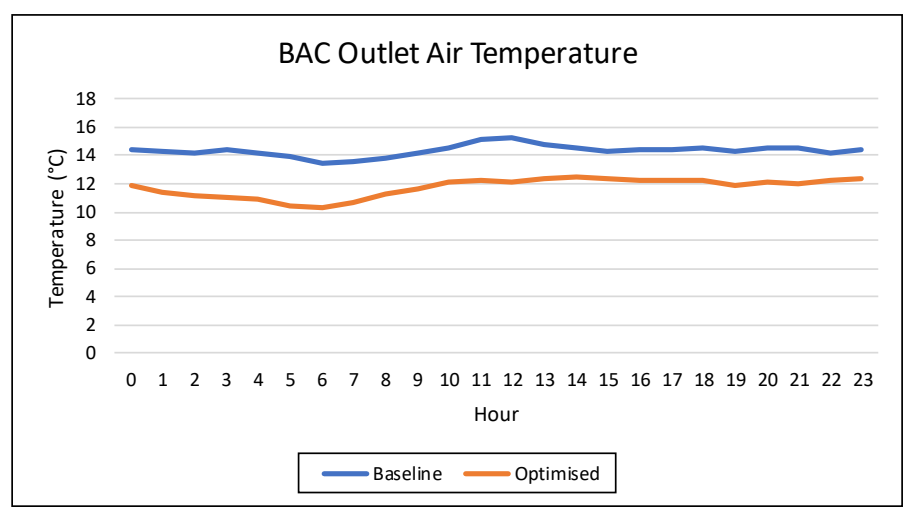

Figure 8: Average BAC outlet air temperature comparison - summer (see online version for colour)

The reduced power consumption of the system was, in part, as a result of the reduced water demand by the BACs. This flow reduction was achieved by running fewer BACs on average, due to colder system temperatures. Figure 9 shows the average BAC water flow comparison. As illustrated in Figure 8 , this reduction in chilled water flow to the BACs did not negatively influence the underground cooling of the mine. The average chilled water flow entering the SCD remained constant at an average of $469 \mathrm{l} / \mathrm{s}$, resulting in increased thermal storage after optimisation.

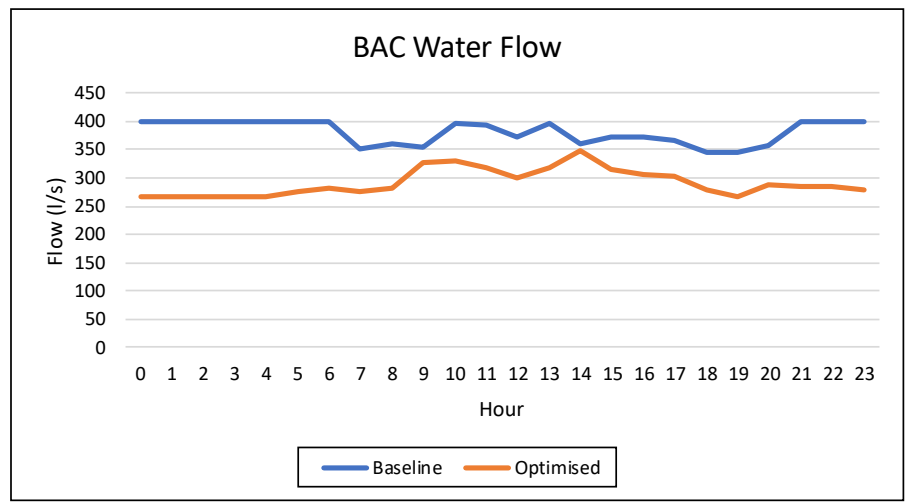

Figure 9: Average BAC water flow comparison - summer (see online version for colour) 
An increase in chilled water recycling of $400 \mathrm{l} / \mathrm{s}$ also occurred for short periods at a time, in certain circumstances. This increased recycling of water at a lower temperature resulted in a $1.4^{\circ} \mathrm{C}$ decrease in chiller evaporator inlet temperatures. This is because PCD2, which is the chiller inlet reservoir, received all the additional recycled water. This reduced the power consumption of the system even further, as less energy was required by the chillers to reach the specified evaporator outlet set-point. This culminated in the shutdown of an entire chiller for large parts of the day, making up the bulk of the $38 \mathrm{MWh}$ daily energy savings recorded over this period. Figure 10 shows the summer power comparison between the baseline and optimised periods.

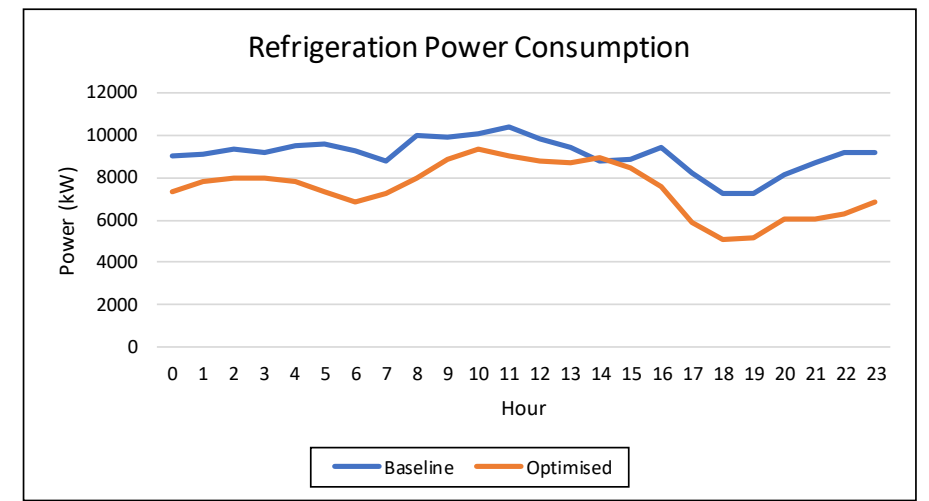

Figure 10: Average refrigeration power consumption comparison - summer (see online version for colour)

\subsection{Winter}

For the winter period, the basic results mirrored those of the summer period. Cooling and energy usage were decreased, with COP increasing by four per cent after optimised control had been implemented. In contrast with the summer period results, an increase in evaporator outlet water temperature was measured. This caused the SCD and BAC outlet air temperatures to increase slightly by $0.4^{\circ} \mathrm{C}$ and $0.7^{\circ} \mathrm{C}$ respectively. Figure 11 and Figure 12 show the comparison for the SCD and BAC outlet air temperatures.

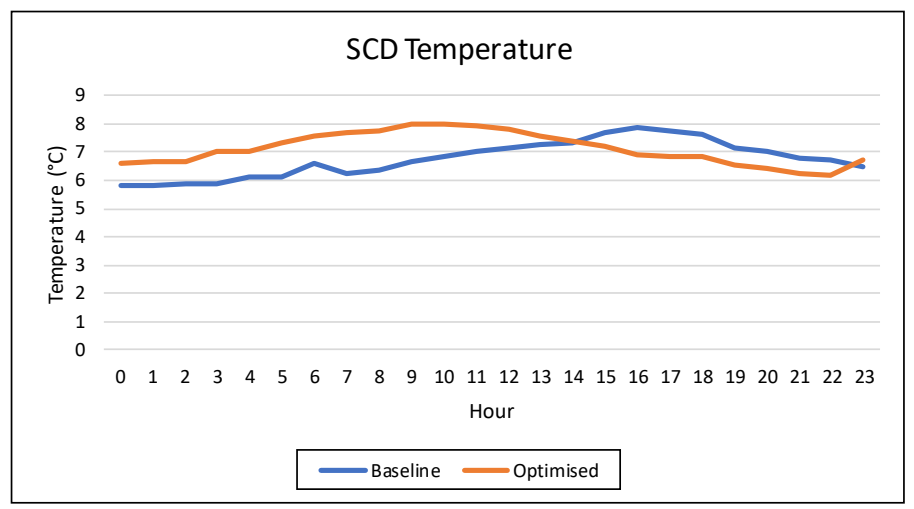

Figure 11: Average SCD temperature comparison - winter (see online version for colour)

Overall, $67 \mathrm{l} / \mathrm{s}$ less water was sent to the SCD during the winter period. This was due to mining personnel preferring the increased energy savings during this period. Large decreases in water flow to the BACs were also present, as illustrated in Figure 13. All of this, however, did not negatively influence the underground cooling of the mine, as the ambient temperature measured on $63 \mathrm{~L}$ remained unchanged. 


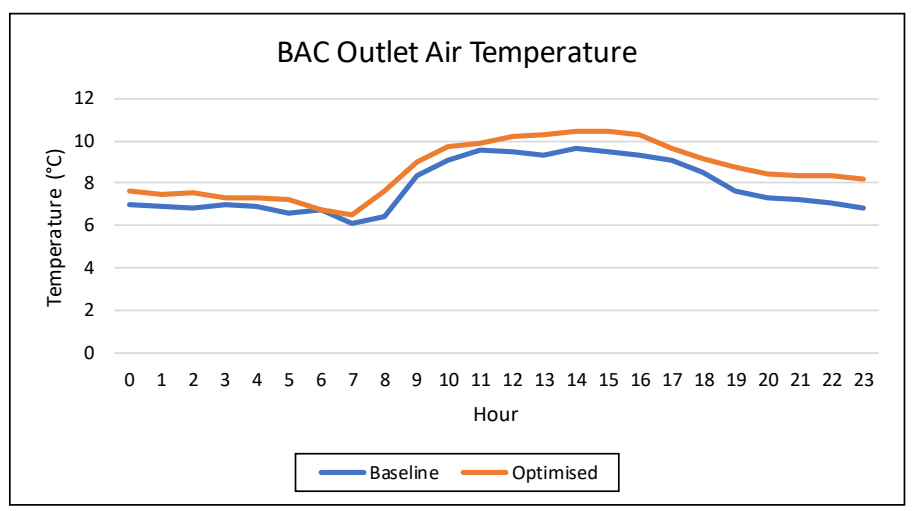

Figure 12: Average BAC outlet air temperature comparison - winter (see online version for colour)

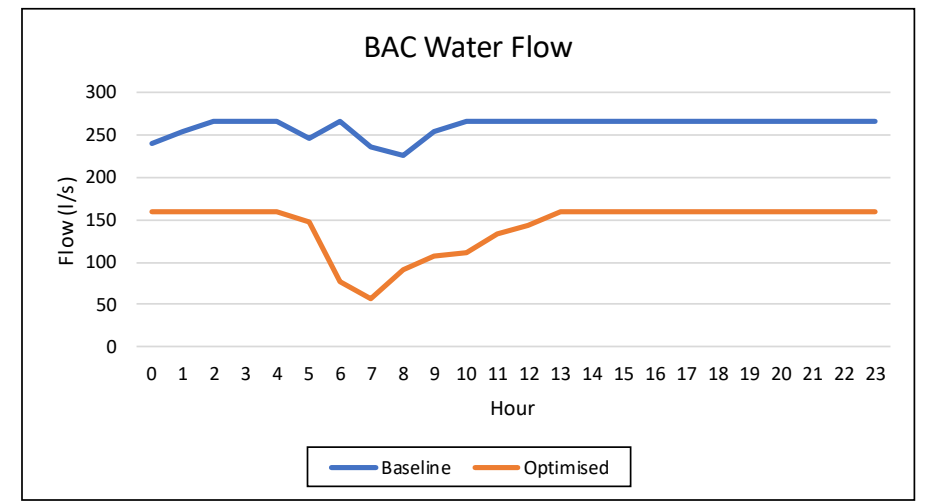

Figure 13: Average BAC water flow comparison - winter (see online version for colour)

Mine A requested that the control philosophy remain in place due to the high cost of electricity during the winter months. Mining personnel were satisfied with the temperature of the air being sent underground, as it remained below the optimised summer temperatures. Figure 14 shows the comparison between the summer and winter BAC outlet air temperatures.

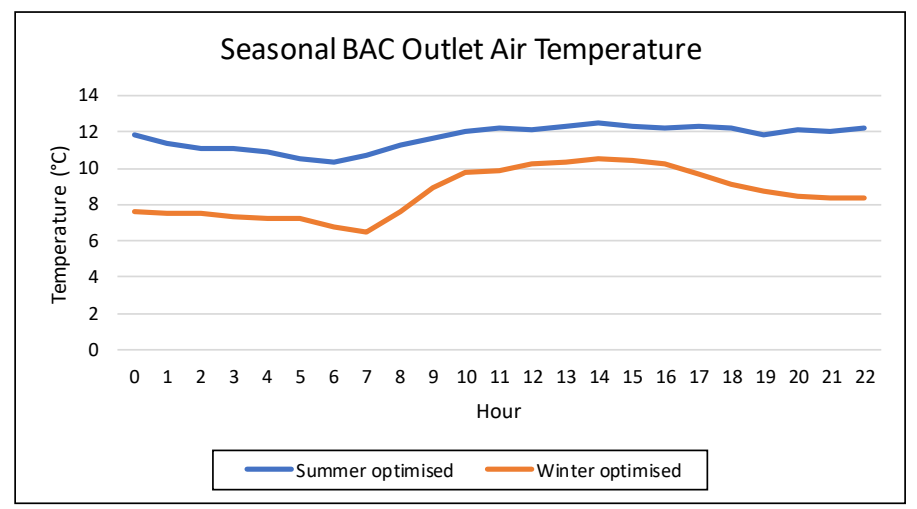

Figure 14: Seasonal BAC outlet air temperature comparison (see online version for colour)

Water and air temperature increases of less than $1^{\circ} \mathrm{C}$ were acceptable for mine personnel when considering the energy saving of $37.5 \mathrm{MWh}$ per day. Figure 15 shows the winter power comparison between the baseline and optimised periods. 


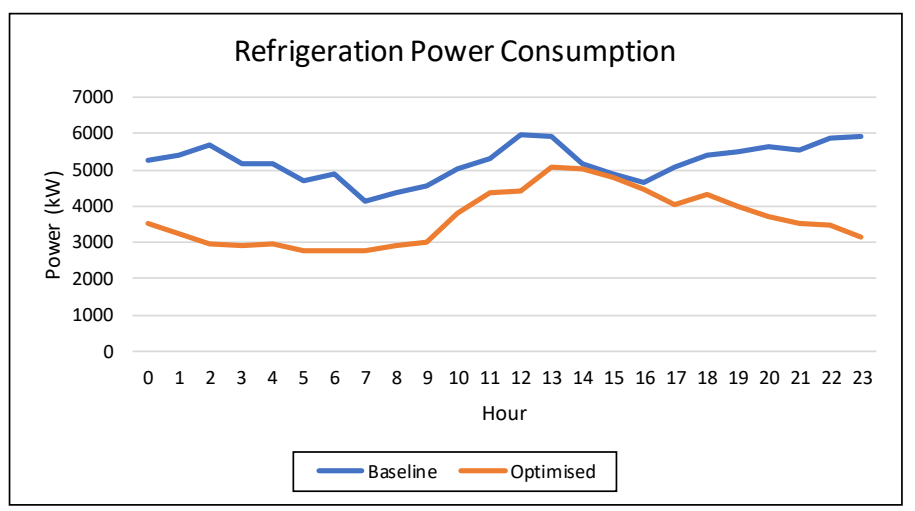

Figure 15: Average refrigeration power consumption comparison - winter (see online version for colour)

\subsection{Summary}

A summary of the main results of the refrigeration system after implementation of dynamic optimised control strategies can be seen in

Table 3. The tabulated values are colour-coded, with red representing negative, green positive, and orange a neutral result. Considering these results, the following can be concluded: dynamic optimisation of deep-level mine refrigeration control can indeed improve operational performance. As previously mentioned, mine personnel requested that the control be biased towards energy savings during the winter months due to increased tariffs imposed by Eskom. This resulted in a decrease in service delivery during winter months. Even with the control optimised for energy savings during winter, all important operational parameters remained below summer levels. Major energy savings were also present during both summer and winter months after optimised control was implemented. This energy saving equates to an approximate electricity cost reduction of R 9 million per annum.

Table 3: Results summary

\begin{tabular}{|c|c|c|}
\hline \multirow[b]{3}{*}{ Evaporator set-point adjustment } & \multicolumn{2}{|c|}{ Operational change } \\
\hline & Summer & Winter \\
\hline & $3^{\circ} \mathrm{C}$ & $3^{\circ} \mathrm{C}$ \\
\hline Coefficient of performance & $5 \%$ increase & $4 \%$ increase \\
\hline Total cooling & $15 \%$ decrease & $32 \%$ decrease \\
\hline Energy usage & $18 \%$ decrease & $30 \%$ decrease \\
\hline Evaporator exit temperature & $15 \%$ decrease & $4 \%$ increase \\
\hline Surface chill dam temperature & $16 \%$ decrease & $5 \%$ increase \\
\hline Flow to surface chill dam & Unchanged & $14 \%$ decrease \\
\hline BAC exit air temperature & $18 \%$ decrease & $10 \%$ increase \\
\hline BAC water flow & $24 \%$ decrease & $45 \%$ decrease \\
\hline $63 \mathrm{~L}$ ambient temperature & Unchanged & Unchanged \\
\hline Pre-cool dam 2 temperature (chiller inlet) & $10 \%$ decrease & $2 \%$ decrease \\
\hline
\end{tabular}

\subsection{General impact of results on industry}

The results of this study prove that optimisation of control can not only reduce operating costs, but also improve operational performance in terms of service delivery on deep-level mine refrigeration systems. However, this concept is not limited to refrigeration systems or deep-level mines. Its application should be investigated for other systems in different industries. Through implementation of this method, improvements in performance and reduction in operating costs can be achieved with cost-effective methods. Over and above the financial implications, implementation periods make these types of initiatives attractive to industry, as timelines are drastically reduced when reconfiguration or infrastructure alterations are not present. 
As this study relied on practical experience of the system in conjunction with basic simulations, improvements to the method are possible using detailed simulation software. Previous studies have proven the accuracy of simulation software in duplicating the operation of complex systems [3], [8], [9], [13], [17], [19], [22]. With the dawn of Industry 4.0, system parameters can be directly supplied to simulation software packages. This will allow the use of real-time simulation software continuously to update the control of a specific system to achieve optimal performance with any given set of inputs. Using these powerful tools to implement complex dynamic control will no doubt result in a further increase in benefits.

\section{CONCLUSION}

The importance of deep-level mine refrigeration systems becomes evident when taking safe environmental conditions for underground workers into consideration. Control of these systems is heavily integrated, and can be quite complex, providing the opportunity to investigate altering this control to improve operation. Ample research is available on control optimisation on deep-level mine refrigeration systems for cost savings. However, this research has focused on control optimisation for cost/savings benefit. None of the evaluated studies focused solely on control optimisation with the goal of improving the operational performance of deep-level mine refrigeration systems.

Shortcomings in existing control were identified on deep-level mine refrigeration systems. It was found that some refrigeration systems are still operated in line with the original design specifications, even though most of these machines are a few decades old. This study focused on improving the performance of existing refrigeration systems on deep-level gold mines through control strategy alterations. This meant updating the control for current operations, as mines expand over time and their cooling needs change.

A dynamic control strategy was implemented on a case study at a South African deep-level gold mine. Custom control was implemented for both summer and winter periods, with the control strategy dynamically altering the evaporator flow to account for changes within the system. Implementation of dynamic optimisation proved successful, as the average performance increase present on the refrigeration system for summer and winter was five per cent and four per cent respectively. During summer months the surface chill dam water temperature was reduced by $1^{\circ} \mathrm{C}$, with the average temperature of the air being sent underground decreasing by $2.6^{\circ} \mathrm{C}$.

In addition to these performance increases, substantial energy savings were also present, resulting in a reduction of about $38 \mathrm{MWh}$ each day. This amounts to a cost saving of R9 million per annum. Dynamic optimisation of deep-level mine refrigeration control was proven effective in improving system performance, with the additional benefit of energy cost savings being present.

\section{REFERENCES}

[1] Duddu, P. 2013. The top ten deepest mines in the world. Mining technology. [Online]. Available: https://www.mining-technology.com/features/feature-top-ten-deepest-mines-world-south-africa/. [Accessed: 06-May-2018].

[2] Neingo, P.N. and Tholana, T. 2016. Trends in productivity in the South African gold mining industry. Journal of the Southern African Institute of Mining and Metallurgy, vol. 116, no. 2, pp. 8-11.

[3] Jansen van Rensburg, F.G., Bredenkamp, J.I.G. and van Rensburg, J.F. 2017. Optimising load management on a deep-level mine's refrigeration systems through maintenance and operational improvements, in Proceedings of the Industrial and Commercial Use of Energy, ICUE, p. 8.

[4] Stephenson, D. 1983. Distribution of water in deep gold mines. International Journal of Mine Water, vol. 2, no. 2, pp. 21-30.

[5] Lane, A., Guzek, J. and van Antwerpen, W. 2015. Tough choices facing the South African mining industry. Journal of the South African Institute of Mining and Metallurgy, vol. 115, no. 6, pp. 471-479.

[6] Bredenkamp, J.I.G. 2016. An integrated energy management strategy for the deep-level gold mining industry. Dissertation submitted in partial fulfilment of the requirements for the degree of Philosophiae Doctor of Engineering, Potchefstroom Campus of the North-West University.

[7] Ruffini, A. 2010. The decline of South African gold mining. Engineering \& Mining Journal, vol. 211, no. 5, pp. 30-35.

[8] Oberholzer, K.J. 2016. Reconfiguring mine cooling auxiliaries for optimal operation. Dissertation submitted in fulfilment of the requirements for the degree of Master of Engineering, Potchefstroom Campus of the North-West University. 
[9] Mare, P. 2015. Improved implementation strategies to sustain energy saving measures on mine cooling systems. Dissertation submitted in fulfilment of the requirements for the degree of Master of Engineering, Potchefstroom Campus of the North-West University.

[10] Sorensen, P. 2011. Mining in South Africa: A mature industry? International Journal of Environmental Studies, vol. 68, no. 5, pp. 625-649.

[11] Baily-McEwan, M. 2016. Mine refrigeration: Machinery and performance assessment, first ed. Johannesburg, South Africa: Mine Ventilation Society of South Africa.

[12] Sonntag, R.E., Borgnakke, C. and Van Wylen, G.J. 2002. Fundamentals of thermodynamics, sixth ed. New York, Wiley.

[13] Schoeman, W. 2014. The integrated effect of DSM on mine chilled water systems. Dissertation submitted in fulfilment of the requirements for the degree of Master of Engineering, Potchefstroom Campus of the North-West University.

[14] RSA Goverment. 1996. Mine Health And Safety Act 1996, vol. 29, no. 967, p. 73.

[15] Moropa, T.S., Marais, J.H. and Schutte, A.J. 2017. Cost and energy savings on mine surface cooling systems, in Proceedings of the Conference on the Industrial and Commercial Use of Energy, ICUE, p. 6.

[16] Sayers, A.T. 1990. Hydraulic and compressible flow turbomachines. London: McGraw-Hill.

[17] Engles, J. 2015. Cost effective control of a platinum mine cooling system using combined DSM strategies. Dissertation submitted in fulfilment of the requirements for the degree of Master of Engineering, Potchefstroom Campus of the North-West University.

[18] Nel, A.J.H., van Rensburg, J.F. and Cilliers, C. 2017. Improving existing DSM initiatives on mine refrigeration systems for sustainable performance, in Proceedings of the Conference on the Industrial and Commercial Use of Energy, ICUE, p. 7.

[19] Peach, P.F.H., Kleingeld, M. and Bredenkamp, J.I.G. 2017. Optimising deep-level mine refrigeration control for sustainable cost savings, in Proceedings of the Conference on the Industrial and Commercial Use of Energy, ICUE, p. 8.

[20] Schutte, A.J. 2007. Demand side managment of a cascade mine surface refrigeration system. Dissertation submitted in fulfilment of the requirements for the degree of Master of Engineering, Potchefstroom Campus of the North-West University.

[21] Schutte, A.J. 2013. An integrated energy-efficiency strategy for deep-mine ventilation and refrigeration. Dissertation submitted in partial fulfilment of the requirements for the degree of Philosophiae Doctor of Engineering, Potchefstroom Campus of the North-West University.

[22] Van der Bijl, J. 2007. Sustainable DSM on deep mine refrigeration systems - A novel approach. Dissertation submitted in partial fulfilment of the requirements for the degree of Philosophiae Doctor of Engineering, Potchefstroom Campus of the North-West University.

[23] Vermeulen, J. 2015. Cost effective management strategies for platinum mine cooling systems. Dissertation submitted in fulfilment of the requirements for the degree of Master of Engineering, Potchefstroom Campus of the North-West University.

[24] Bredenkamp, J.I.G., Mathews, M.J. and Vosloo, J.C. 2016. An integrated energy management strategy for the deep-level gold mining industry, in Proceedings of the Conference on the Industrial and Commercial Use of Energy, ICUE, pp. 133-138. 